\title{
FACTORS CONTRIBUTING TO CHILD SEXUAL ABUSE BY TEACHERS IN SCHOOLS: A STUDY OF MASVINGO DISTRICT SECONDARY SCHOOLS
}

\author{
Magwa Simuforosa $^{1}$ and Ngara Rosemary ${ }^{2}$ \\ ${ }^{1}$ Zimbabwe University, faculty of education, Department of educational Foundations, Masvingo, Zimbabwe \\ magwasf@gmail.com \\ ${ }^{2}$ Zimbabwe Open University, Faculty of Education, Midlands Region, Gweru, Zimbabwe \\ rosemaryngara@gmail.com
}

\begin{abstract}
Learners are at risk of sexual abuse by teachers. This study set to explore the perceptions of learners, teachers and educational psychologists on child sexual abuse in schools. The study is informed by Maslow's hierarchy of needs. In an attempt to provide acceptable answers to research problem the qualitative phenomenology design was employed and semi-structured interviews were used to collect the data. Purposive sampling was used to select schools and participants in Masvingo district. The schools selected were 4 and participants were 19 Accepted ethical measures were adhered to during the study. Tesch's open coding method of data analysis was used to identify themes and categories. The study found out that child sexual abuse in schools is rampant and that teachers are among the perpetrators of this abuse. Child sexual abuse was said to fall into two categories namely; contact or non -contact sexual behaviour. According to the results of the study multiple factors cause teachers to sexually abuse. Some of these factors include abuse of power by teachers, poverty of learners, lust on the part of the teacher, and disregard of law by teacher. Students were said to be contributors of their own sexual abuse through their seductive behaviours and dressing. In light of these findings recommendations are made with regards to the need for how various stakeholders in the school namely; the Ministry of Primary and Secondary Education, Zimbabwe, policy makers, school heads, teachers, parents and learners to thoroughly understand the forms and root causes of child sexual abuse so as to be able to fight this scourge.
\end{abstract}

Key words: Child, Learner, School, Child sexual abuse, Perception, Teacher

Academic Discipline And Sub-Disciplines: Education/Psychology

\section{Council for Innovative Research}

Peer Review Research Publishing System

\section{Journal: Journal of Social Sciences Research}

\author{
Vol. 8, No.1 \\ jssreditor.cir@gmail.com
}

www.jssronline.com 


\subsection{INTRODUCTION AND BACKGROUND TO THE STUDY}

Kibaru-Mbae (2011) asserts that child sexual abuse is a human rights issue with serious negative public health consequences including physical, psychological, emotional and social effects. Heiberg (2005:14) asserts that child sexual abuse crosses national boarders and is a concern of the global community.

Evidence of child sexual abuse by teachers has been gathered in many countries. Gaye (2012) reports that in Cape Town, South Africa, 38 teachers have been struck off the roll for sexually abusing and impregnating learners since 2010 . Three teachers from Gauteng, South Africa at Phahama secondary school in Randfontein in 2012 were suspended for alleged sexual misconduct against learners, following complaints by 8 learners. Zimbabwean school children under 18 years continue to bear the brunt of sexual abuse from educators in the schools. Gwirai (2011) carried out a study on child sexual abuse in Gweru district schools of the Midlands province of Zimbabwe. Out of 268 respondents, 151 reported having been sexually abused giving an overall prevalence rate of $56,3 \%$. Learning institutions have gained notoriety as venues of sexual assault (Richter \& Higson Smith 2004:23). Inappropriate sexual relations between staff members and learners are a growing worldwide concern in the education system which tarnishes the reputation of schools. Shumba (2009:19) asserts that abuse of learners by teachers in schools is a social problem locally in Zimbabwe and globally.

\subsection{THEORETICAL FRAMEWORK}

This study is informed by Maslow's hierarchy of needs theory. His theory is a motivational theory with five levels that argues that while people aim to meet basic needs they seek to meet higher needs. The five needs are discussed below.

Physiological needs- Maslow asserts that physiological needs include food, water, air, and sleep (Reid-Cunningham, 2008). Clothes and shelter are important for protection. According to Maslow if such needs are not satisfied then one's motivation will arise from the quest to satisfy them (http://www.netmba.com/mgmt/ob/motivation/maslow). In the school situation learners from a poor background may like some of the basic needs such as food, clothing, and money to buy basic needs and as a result they will engage in transactional sex where they will receive money to buy basic needs in exchange of sex.

Safety needs- Once physiological needs are met one's attention is drawn to safety and security needs. Maslow (1954) says within this framework the human being yearns for a predictable, orderly world in which unexpected and unfamiliar things are rare. Sexual abuse of learners is a dangerous and unexpected event to the learner. Schools are no longer safe places for learners if sexual abuse takes place.

Love and belonging- These needs are described in terms of social relationships, connections with other people and belonging to groups. If teachers sexual abuse learners the learners will feel that the teachers do not love them for they do not care for their human rights. There can be significant damage to individual's psychosocial functioning when love and belonging needs are seriously threatened (Reid-Cunningham, 2008).

Esteem Needs- include desire for a high and accurate assessment by oneself as well as need for others to appraise the individual as worthy (Martin and Joomis, 2007). Sexually abused learners feel ashamed, and guilty, their esteem is reduced. Thwarting of one's self esteem needs can produce psychopathology especially insecurity, helplessness, and inferiority complexes.

Self- actualisation-Maslow applied the term to describe the process through which human beings embody their full potential. He described the possibility of pursuing higher level goals within the context of partial satisfaction of the basic needs (Reid-Cunningham, 2008). Learners due to sexual abuse perform poorly, drop out of school and thus, fail to self actualise.

\subsection{AIM}

The main aim of this study is to establish the various factors which causes teachers to sexually abuse learners in schools.

\subsection{RESEARCH QUESTIONS}

i)What are the different forms of child sexual abuse?

ii) Which are the factors that contribute to child sexual abuse in schools by teachers?

\subsection{RESEARCH DESIGN AND METHODOLOGY}

This section focuses on the design and methodology adopted by the study.

\subsubsection{Research approach and design}

This study employed the qualitative phenomenological design. Tewsbury (2009:54) asserts that qualitative research primarily focuses on micro level issues. In this qualitative research study focus was on a small number of participants (19) in order to provide in-depth, detailed information about sexual abuse in schools by teachers. In the case of this study, opportunity was created for participants to speak for themselves in their natural settings on forms of child sexual abuse and contributing factors of the abuse. The qualitative phenomenological inquiry relied on tape recorded interviews whilst exploring the phenomenon in greater depth (Ganga, 2013:88). Phenomenology aims to develop a complete, accurate, clear and articulate description and understanding of a particular human experience. With this in mind, this study aimed to 
describe in depth and as accurately as possible the phenomenon of child sexual abuse as a negative human experience in schools. Capturing the perspectives of participants is thus a major purpose of this qualitative phenomenological study. Phenomenology places special emphasis on the individual's views and personal experiences (Denscombe, 2007:76).

\subsubsection{Sampling}

Merriam (1998:60) defines sampling as the selection of a research site, time, people and events in field research. Sampling is crucial since there is not enough time, energy, money and equipment to measure every single item or site within an entire population (Chiromo 2006:16). The participants were drawn from a population of secondary school learners, secondary school teachers and educational psychologists in the Masvingo district in Zimbabwe. To select the sample, this study adopted a non-probability sampling method. Oliver (2010:109) emphasises that non-probability samples, typical of research within a qualitative perspective are usually much smaller than in quantitative research, but collected data is more detailed than in the case of probability samples. Within non-probability sampling, a sample was drawn using purposive sampling. Oliver (2010:109-110) defines a purposive sample as a sampling method in which the researcher identifies certain participants as being potentially able to provide significant data in the study. Information-rich cases are those from which one can learn a great deal about the phenomenon being studied which in this case is child sexual abuse.

\subsubsection{Data collection technique}

Burns and Grove (2003:373) comment that data gathering is a precise, systematic gathering of information relevant to the topic with its sub problems/questions, using various tools. Tools, according to Khan (2008:97) are the ways and means to conduct research. This study used qualitative interviews to get information concerning child sexual abuse by teachers in schools from participants.Qualitative interviews are believed to provide a deeper understanding of social phenomena than would be obtained from purely quantitative methods such as questionnaires (Gill, Stewart, Treasure \& Chadwork, 2008:292 and Holloway, 2005:39). Tichapondwa (2013:127), Ary, Jacob and Razavieh, (2010:380); Chiromo, (2006:26); as well as Burns and Grove (2003:280-283) point out that qualitative interviews are flexible which is one reason why they were seen as appropriate for this research. There was direct human interaction that enabled probing and clarifying questions, misunderstood by the participants.

\subsubsection{Data analysis}

Qualitative data analysis as echoed by Denscombe (2007:307) is the process of bringing order, structure and interpretation to the mass of collected data. This study was qualitative in nature and the narrative data came from interview transcripts and fields notes. The data was analysed using Tesch' method which includes steps such as data collection, displaying it, reflecting on it, coding and distilling it into themes, sorting data into categories and sub categories, formatting it into a coherent story and writing the qualitative text story (De Vos, Strydom, Fouche \& Delport, 2012: 343).

\subsubsection{Ethical considerations}

Research ethics demands that human beings should be treated with respect and should not be harmed in any way (Oliver, 2010:12). Permission was also sought from the Ministry of Primary and Secondary Education (Zimbabwe), Masvingo Provincial Education Office, and school heads of selected schools. Teachers and educational psychologists gave their consent. Learners gave assent with consent from their parents to take part in the research. Prospective participants were informed about the purpose of the study, potential benefits, kind of involvement, estimated time for the interview, what will be done with the data .Participant's identity has to be preserved, at all costs by the researcher (Rudestam \& Newton, 2007). Participants were assured that the information will be treated with strict confidentiality. The right for participants to withdraw from participation without penalty is a principle of respect (Matlala et al., 2014:4). The participants were also informed that withdrawing from the study will not affect them in anyway.

\subsection{KEY FINDINGS}

This section presents and analyses the findings basing on the research questions.

\subsubsection{Research Question 1: Which are the different forms of child sexual abuse?}

Participants were asked the behaviours which constitute child sexual abuse. Their responses are reflected in figure 1 below: 


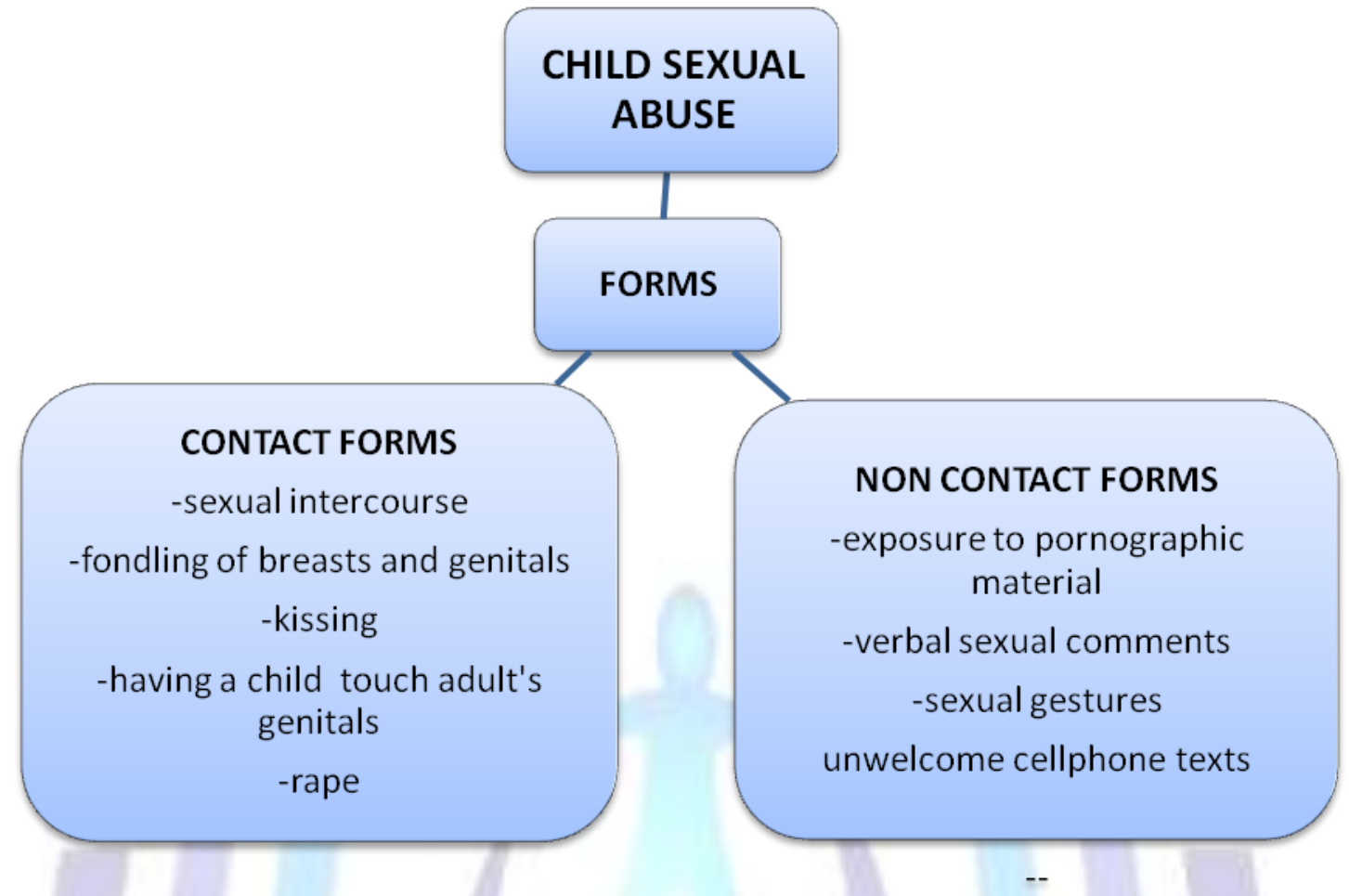

Fig 1: Behaviors which constitute child sexual abuse as identified by the participants.

As is reflected from the table above sexual intercourse was rated the most common form of contact sexual abuse by 14 participants $(73.7 \%)$, followed by fondling of breasts, genitals or private parts and sexual comments and jokes each with 11 participants, $(57.9 \%)$ and then sexual gestures 10 participants $(52.6 \%)$. The rest of the forms were mentioned by less than half of the particpants with unwelcome cellphone messages and calls being rated the least form by 3 participants, (15.8\%).

\subsubsection{Research Question 2: What are the factors that contribute to child sexual abuse in schools?}

The graph below illustrates the array of contributing factors mentioned by participants.

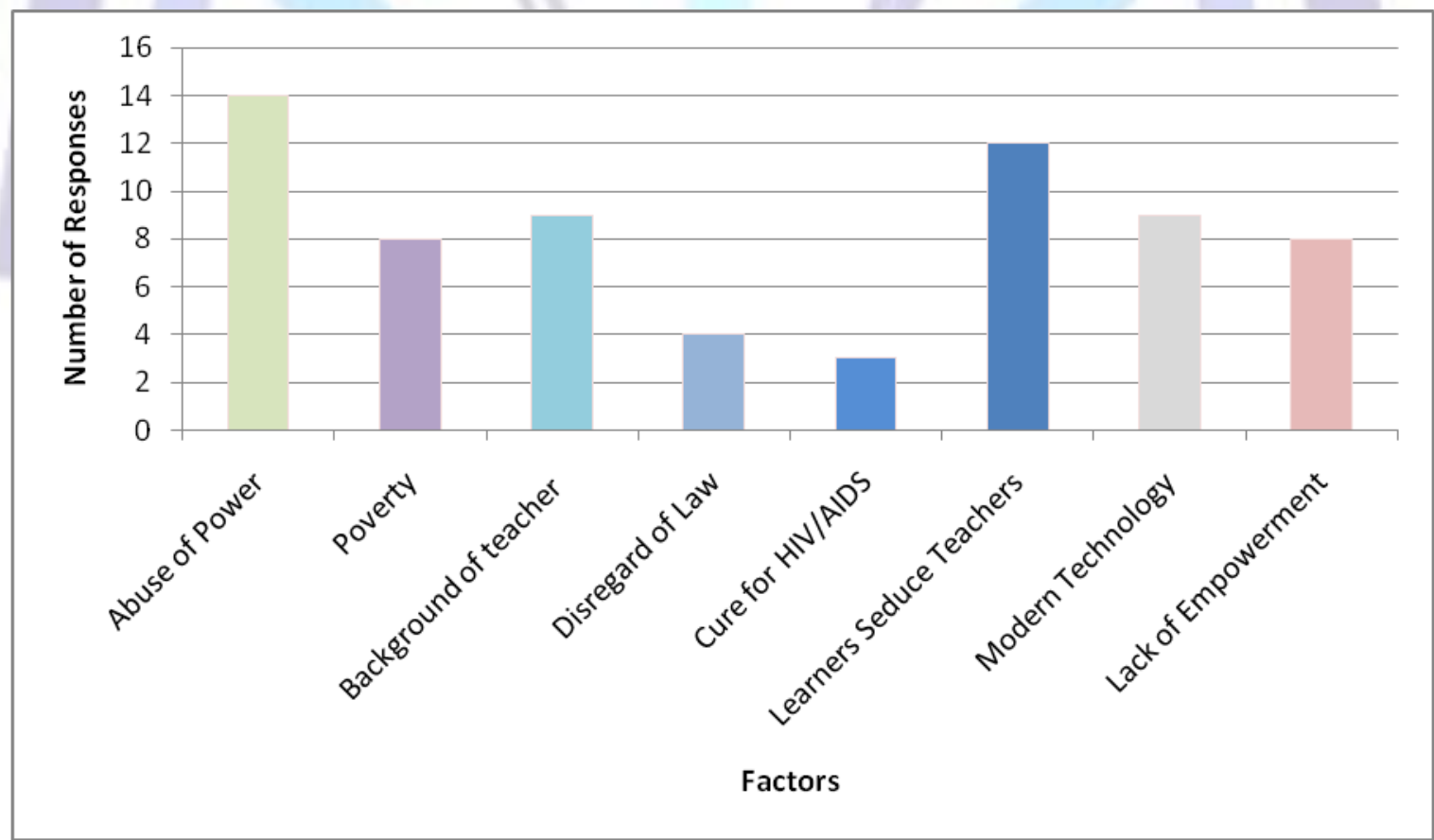

Figure 2: Factors contributing to child sexual abuse by teachers 
An overwhelming number of participants 14 out of $19(73.7 \%)$ as reflected in the graph stressed that misuse of authority and positions of trust by teachers lead to child sexual abuse by teachers in schools.

This study identified poverty as one of the factors responsible for and contributing to the vice of child sexual abuse in schools. A total of $42.1 \%$ were of the view that due to poverty learners are targeted by teachers and learners themselves engage in sexual relations with teachers so as to alleviate their poverty.

One of the responses participants gave to the question why teachers sexually abuse learners had to do with the teacher's background. Quite a number of participants, 9 out of 19 (47.4\%) mentioned that background of teacher can contribute to sexual abuse of learners. Issues raised under this causal factor include: personality trait, where lust prevails, teachers seek to gratify their sexual needs by ravaging learners, the teacher abuser was also sexual abused when young, that is, the victimizer-as- victim hypothesis and the teacher experiencing problems in own marriage.

One very crucial contributor of child sexual abuse established by this study was that abuse is a product of low levels of awareness on forms of sexual abuse and learners' rights regarding how other people especially teachers should handle them. A handful of participants 8 out of $19,(42.1 \%)$ underlined that victims often fail to recognize some behaviors as sexual abuse because they are not well informed on what constitutes child sexual abuse.

\subsection{DISCUSSION}

The study revealed that child sexual abuse includes both contact and non-contact acts. Participants identified contact forms of sexual abuse as including speaking in a derogatory way about the learner's, showing pornography, sending love messages. On the other hand, contact sexual abuse was said to involve actual body contact between the abuser and child for example, sexual intercourse, touching on buttocks and /or breasts, and kissing.

The study findings match well with findings in a study by Shumba on perceptions of child sexual abuse by teacher trainees in Zimbabwean schools, participants indicated that sexual abuse of pupils in the school context involved sexual intercourse with pupils, fondling pupils' breasts, buttocks and private parts, showing pornographic materials and passing sexual comments (Shumba, 2006:1)

It emerged that learners are in a power inequality bond where an arena of sexual abuse is created by the authority teachers have over the learners. They are easily targeted since they are socialized to obey adults. Transactional sex that is trading sexual favors with students was also cited as a sign of power. The following statement by one Educational Psychologist illustrates many participants' views on this contributing factor. Teachers have ascribed authority. Their relationships with students are based on relationships of superiority. They use their power as a weapon to lure students who because of their socialization are taught to obey. In such a case the student will comply with whatever the teacher demands.

Similarly, a UNICEF study of West and Central Africa carried out at the regional offices in 2006 on persistent sexual abuse and exploitation of children at school concluded that the most frequently cited situations of sexual abuse in the 23 countries are based directly on the position of authority occupied by teachers. The teacher -student relations were said to be marked by an abuse of authority based on the legitimate relation of superiority between teacher and student. Furthermore, in a Liberian research on sexual abuse in schools $18 \%$ of school girls and $13 \%$ of school boys reported having been asked for sex to get a good grade.

The study established that poverty on the part of learners contribute to the learners engaging in child sexual abuse. If parents fail to pay costs related to school, girl children were said to use their bodies as economic assets to get rid of the economic pressure. This assertion is illustrated in the words of a male learner who had this to say: Girls especially from a poor background engage in sexual relationships with teachers so that they will have money to afford such things like cosmetics, and pocket money. At this stage compared to boys and due to peer pressure girls especially would also like to be like those who can afford. Thus, students not only engage in transactional sex to obtain better grades but also due to economic hardships. It was also noted that teachers utilize the poor situation of some learners and sexually abuse them in the process of taking care of their needs. One teacher lamented.

The results corroborate the findings by Chinyoka who carried out a study in 2013 in Masvingo district of Zimbabwe on psychosocial effects of poverty on academic performance of the girl child in 3 schools. The study found that teachers take advantage of poor vulnerable girl learners and ask for sexual favors in return for economic benefits. In return, according to findings of the study, in some instances the girls were given stationary and favors in class (Chinyoka, 2013). Some of the relationships between teachers and poor girls were said to have the approval of parents who perceive them as possible route to financial assistance for the household. Data yielded from the study has clearly shown that due to economic hardships some teenagers initiate contacts with teachers for material gain. Many children desire for things beyond the ability of their parents.

Orphan-hood was also given as an example of a serious driver to sexual abuse by teachers. Orphans usually lack school fees and have an overwhelming responsibility of looking after other siblings. Some teachers as revealed by the study find these orphan learners easy prey to satisfy their sexual drives.

The study findings also revealed that the teacher's background had a lot to do with sexual behavior. Within this framework it was pointed other teachers sexually abuse learners simply because it is in their genes that is hereditary. Others may sexually abuse because they were also sexually abused when they were young and would therefore feel like revenging, 
though not to the abuser. Some teachers do not get enough sexual satisfaction with their wives and by engaging in sex with students they want to quench their sexual thirst.

From his study on etiology of sexual abuse in schools, Shumba interviewed education officers. The education officers revealed that that most cases of sexual abuse in schools tend to involve young teachers who are married and who seem not satisfied with their marriages Shumba (in Smith, 2008: 132).

Research studies have found the victim to victimiser relationship in the context of sexual abuse as an explanation to why abusers sexually abuse (Kring, 2011:106). Several studies have demonstrated that sexual abusers mirrored their own victimization in perpetrating sex against others. In their research on perpetrators of sexual abuse half the survey respondents thought that men who sexually abuse children had been sexually abused themselves (Jones \&Jemott, 2010:11). Jespersen, Lalumiere \&Seto, (2009:18) and Irenyi, Bromfield, Beyer \& Higgins, (2006:8) confirm that experiences of child sexual abuse in childhood to a certain extent contribute to later offending.

However, Richards carried out a study on misperceptions about child sexual offenders in Canberra and found out that not all victims of sexual abuse become perpetrators and not all perpetrators have experienced abuse as children (Richards, 2011). This finding is also consistent with the findings of this study. Thus, biological and personal history factors of the teacher contributes to sexual abuse of learners to some extent.

In their enumeration of causes of sexual abuse by teachers in schools, listed lack of enough understanding of laws governing the conduct of their duty. This finding as noted only emerged from teachers and educational psychologists, maybe because they are more knowledgeable in this area than learners. They also pointed out that poor enforcement of laws resulted in teachers committing more sexual offences. Some school heads connive and collaborate with perpetrators who are their relatives. The heads pretend to be ignorant about the case and this situation promotes sexual abuse of learners in school environment.

Laxity in enforcement of the laws encourages child sexual abuse since the abuser will have noted other abusers getting away with the crime. In line with the findings of this research, a study by Fiscian of 3 government schools in Ghana to gather data on the abuse of girls in schools, there were several cases of teachers having affairs with girls in the school. However, the school and district authorities took little if any, action in response (Plan Germany, 2008:52). Some law enforcement agencies connive with perpetrators to deny justice for victims. The laws have failed to play role of deterring the perpetrator (Opobo \& Wandega, 2011: 23). Similarly, in a study conducted in 70 schools in Kenya with children aged between 10 and 18 years on sexual abuse meted against children, respondents were asked what happened to teachers who made school girls pregnant. The responses are illustrated in Figure 5.9 below. The statistics clearly show that teachers got off very lightly, being punished, transferred, demoted, suspended and the largest percentage $32 \%$ nothing was done to them.

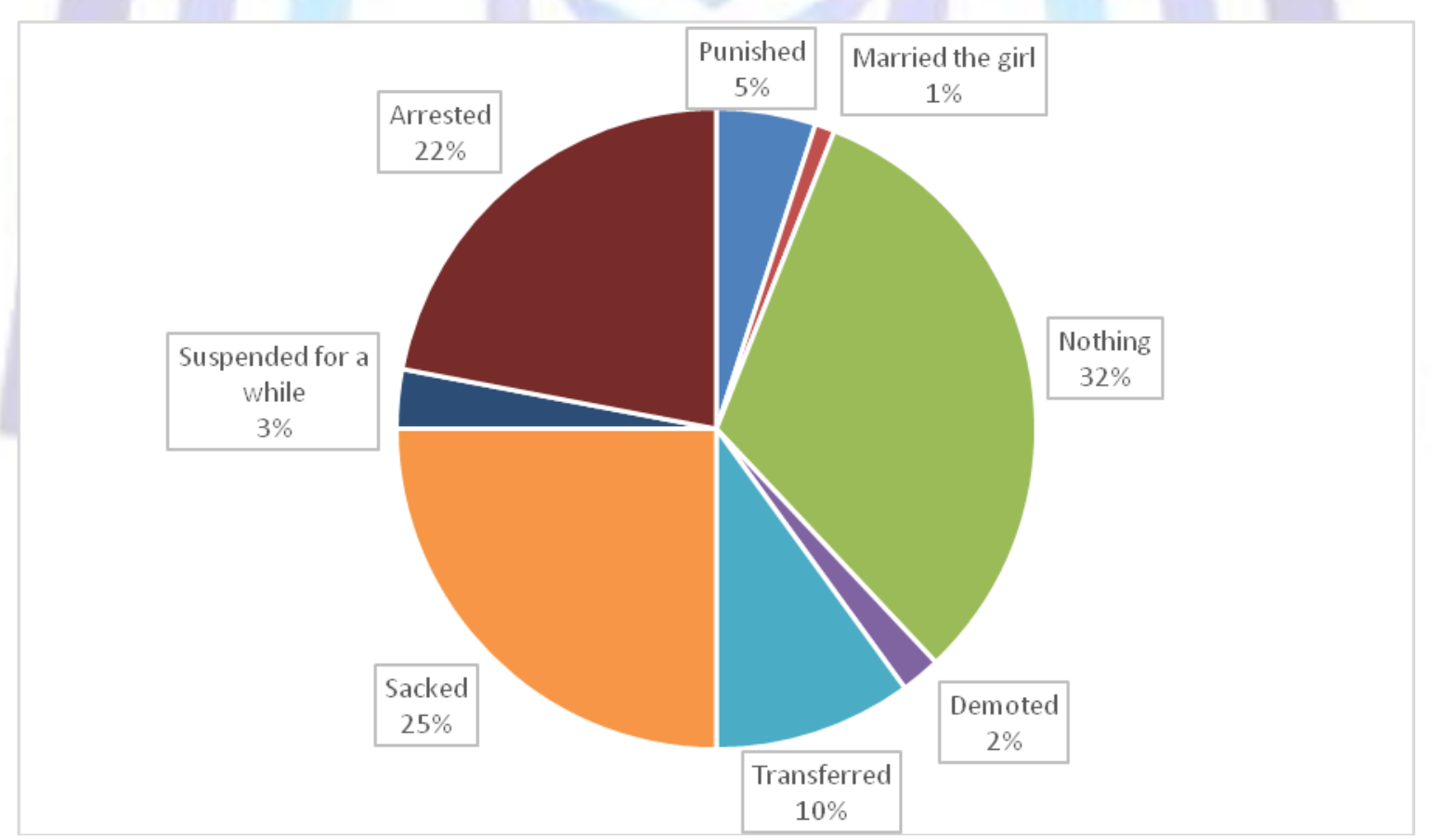

Figure 5.9: Consequences of unwanted pregnancy on teacher perpetrators

Source: Ruto(2006:183).

In Zimbabwe, child sexual abuse is punishable by law. Existing pieces of legislation such as the sexual offences Act 2001, the Protocol on the Multi- Sectoral Management of Sexual abuse and violence in Zimbabwe the Domestic Violence Act (2006) have been harmonized with international law in an effort to protect children against sexual abuse (Gwirayi, 2013:11).

$\mathbf{1 5 2 5} \mid \mathrm{P}$ a g e

June 19,2015 
Participants made it clear that if learners are unaware of their rights this contribute to their sexual abuse as illustrated in the excerpt by a learner: Learners do not know what to do. I think they are not empowered on how to recognise tactics used to lure them to engage in sexual activities. They also do not know how to refuse these advances.

In line with the findings of this research, literature indicates that children are sexually violated in schools because they lack knowledge of their rights, of how to be assertive, of where to report sexual abuse, of not being aware of other forms of sexual abuse other than defilement (Opobo\&Wandega, 2011:15 and Proulx, 2011:34). Of the children who participated in the Child Research and Resource Centre (CRRESCENT) study (2009: 37) 87.2\% did not know of any institution that supports victims of sexual abuse. In a study conducted by Gwirayi \& Shumba 2011 on children's awareness about their rights the study found that most secondary schools learners were not aware about their rights and organisations which deal with their rights. Children' awareness of their rights as opined by Gwirayi \& Shumba denotes some form of empowerment (Gwirayi, 2013:7).

It emerged from the study that modern technology can lead teenagers to engage in sexual activities. Despite the positive impact of informing, educating, and entertaining, modern technology was said to influence secondary school children to become sexually active. Findings of this study revealed that in the school situation learners have access to the internet through their mobile phones where they have access to a lot of sexual material through the social networking cites, video games, and YouTube.

Such perspectives are also reflected in a study by Magwa on the impact of modern technology on the educational attainment of adolescents in Masvingo district where it was found out that teens can download and post sexual videos. It was also found that they also send and receive sexually suggestive messages. According to a survey performed by a London school of Economics in 2002, 90\% of children between 8 and 16 years of age have viewed pornography on internet (Louge, 2006:2). Thus; those exposed to pornographic material through Internet are more likely to report permissive sexual attitudes such as having oral or vaginal sex than youth with less exposure.

Cure for HIV and AIDS was also said to be one reason why some teachers sexual abuse learners. In the words of one female learner, Some teachers who are HIV positive seek treatment from traditional healers who tell them that if they sleep with virgins they will be cured of the virus. These teachers believe in traditional beliefs.

However, some participants felt that cure for HIV and AIDS was just a myth. With regards to the HIV and AIDS cure, in the literature it has been asserted that in some countries still grappling with the issue of HIV and AIDS many adults have opted going in for children. There is a perception and mentality that children are HIV free and hence the safest target (Opobo\&Wandega, 2011:24). Literature ascertain that having sexual intercourse with a virgin cleanses the perpetrator of HIV and AIDS infection (Kibarue-Mbae, 2011:38; Thompson \& Wilkinson, 2010:48; Devasia \& Kumar, 2009:71, and Laror, 2005:10).

One of the major push factors contributing to child sexual abuse by teachers in schools was alluded not to the teachers but to the learners themselves as seducing teachers. Teachers were regarded as victims of sexual abuse by learners. Several reasons have been proffered to explain why learners seduce teachers. Some of these include wanting to meet financial needs due to poverty, their desires are beyond the willingness of parents, peer pressure, hoping to get married, enjoy sexual involvement. It was revealed that female learners especially dress and behave provocatively.

The following quote highlight the overall sentiments of some of the participants: Students, mainly girls, cause teachers to sexually abuse them. They seduce male teachers by the way they dress for instance by wearing miniskirts, transparent clothing, indecent make up and also by sexual gestures they perform in front of teachers. Nevertheless, as rightly put by Maalla M'jid (2008:18) the suggestion that teachers may be victims of sexual abuse by learners seeking to survive or get ahead of school should not override the offence of gross misconduct committed by teachers who give in to engage in sexual relations.

\subsection{SUMMARY}

Child sexual abuse is rampant in schools. Sexual abuse can include contact and non -contact behaviors. Incidents of sexual abuse by teachers include a range of behaviors such as rape, sexual comments and touching, kissing, sharing pornography, and transactional sex for marks, favouritism.

Analysis of data has shown that there are many varied circumstances that result in learners being sexually abused by teachers. In most cases of sexual abuse, abusers possess some form of power or prestige in form of economic, social or physical that is used as a tool to entice or coerce the victim. Girls' low economic power is another cause of sexual abuse. They yield to sex in exchange of marks or tuition money (Proulx, 2011:33). Poor enforcement of the laws and policies, cure for HIV and AIDS, modern technology all cause learners to be sexually abused. Some teacher abusers repeat behaviors learned during their victimization- modelling the abuser's behaviors thereby sexually abusing learners. Learners themselves especially girls children initiating sexual contacts through their seductive dressing and behaviour

\section{REFERENCES}

1. Ary, D, Jacobs, LC. Razavieh, A. 2010. Introduction to research in Education. Cengage

2. Australian Development Agency. 2010. Human Rights manual: Guidelines for implementing a Human Rights based approach. Available at http//www.entwicklung.at (accessed on 21/10/13. 
3. Burns, N. Grové, SK. 2005. The practice of nursing research: Conduct, critique and utilization $: 5^{\text {th }}$ edition. Missouri: Elsevier Saunders.

4. Child Research and Resource Centre (CRRECENT) (2009). Report on the Study of Child Sexual Abuse in Schools. Commissioned by Plan Ghana, Accra.

5. Chinyoka, K. 2013. Psychological effects of poverty on the academic performance of the girl child in Zimbabwe: Unpublished PHD thesis, Pretoria: UNISA.

6. Chiromo, A. 2006. Research methods and statistics in education. A student's guide. Gweru: Beta Print.

7. Denscombe, M. 2007. The good research guide for small scale social research projects. $3^{\text {rd }}$ edition. New York: Open University Press.

8. Devasia, V and Kumar, H. 2009. Social work concerns and challenges in the $21^{\text {st }}$ century.New Dehli: APH Publishing Corporation.

9. Ganga, E. 2013. The effects of double orphan hood on the learning and cognition of children living within childheaded households in Zimbabwe. Unpublished PhD thesis, Pretoria: UNISA

10. Gill, P. Stewart, K. Treasure, E. \& Chadwick, B. 2008. Methods of data collection inqualitative research. Interviews and focus group. British Dental Journal Vol $204 \quad$ (6) 291-295.

11. Gwirai, P., 2011. Child sexual abuse among urban secondary school pupils: Impact of familycharacteristics and family structure. International review of Social Sciences and Humanities Vol. 3, No. 1 (2012), pp. 36-50.

12. Holloway, I. 2005. Qualitative research in health care. Open University Press: Berkshire.

13. Hossan, DM. 2011. Qualitative research process. Postmodern openings, year 2 (7)

14. Irenyi, M, Bromfield, L, Beyer, L \& Higgins, D.2006. Maltreatment in organisations: Risk factors and strategies for prevention. Available at: http:aifs.gov.au (accessed on, 02/07/13).

15. Jerpersen, AF, Lalumiere, ML \& Seto, MC.2009. Sexual abuse history among adult sex offenders and non sex offenderd: a meta analysis. Toronto: University of Lethbridge.

16. Jones, AD \& Jemmott, ET,2010. Perceptions of, Attitudes to and Opinions on Child sexual abuse in the Eastern CaribeanUniversity of Huddersfield. Unicef Barbados and the Eastern Caribean.

17. Kibaru-Mbae, 2011. Child sexual abuse in Sub-Saharan Africa. A review of literature. East, Central and Southern African health Community: World Health Organisation.

18. Kring,JR. 2011.Caught in the cycle of sexual violence: The application of mandatory registration and community notification laws to Juvenile sex offenders. Widener Law Review Vol 18: 99-122.

19. Laror, K. 2004. Child sexual abuse in Sub-Saharan Africa: A literature review: Child abuse and neglect, Vol 28: 439-460.

20. Louge,N. 2006. Research Facts and findings: Adolescents and the Internet. New York: ACT for Youth Center of Excellence.

21. MaallaM'Jid, 2008. Sexual abuse and exploitation of children in west and central Africa. Available www.unicef.org/wcaro/english/ESEWCAROFinalReport EN corrige.pdf( $\quad$ accessed, 04/02/15).

22. Magwa, S. 2013. The impact of modern technology on the educational attainment of adolescents. International Journal of Education and Research Vol. 1 No. 9.

23. Martin, d and Joomis, K(2007) Building teachers: a constuctivisit approach to introducing education. Belmont:CA Wadsworth.

24. Maslow, A. 1954 Motivation and personality. New York: Haiper.

25. Matlala, SF, Nolte,AGW\&Temane,Ma.2014. Secondary school teachers's experience of teaching pregnant learners in Limpopo province, South African Journal of Education, Vol 34 Number 4.

26. Merriam, SB.1998. Qualitative research and case study applications in education. San Francisco: Jossey -Bass.

27. Oliver, P. 2010. The student's guide to research ethics. 2nd edition. Berkshire: Open

28. Opobo,T. \&Wandega, A, 2011. Child sexual abuse in Jinja District-Eastern Uganda. A study commissioned by Jinja district Network for the marginalized child and youth (JINNET). Available www.terrdeshommesnl.org/download/69 (Accessed 05/02/15).

29. Plan Germany, 2008. Learn without fear: Looking at violence from the gender perspective.

Conference: Hamburg; Univesity of Sussex. at:www.learnwithoutfear.de/pdf/Learnwithoutfear_conference_rz.pdf (Accessed 16/02/15). 
30. pp143- 156.

31. Proulx,G. 2011. Male sexual and gender - based violence in schools: Barriers to community strategies for change the case of Awaso, Ghana. Thesis submitted to faculty of Graduate studies in partial fulfillment of the requirements for the degree of Master of Arts in International Development School of International Development and Global studies Sciences University of Ottawa.

32. Reid- Cunningham,AR. 2008. Maslow's theory of motivation and hierarchy of human needs Maslow's Theory of Motivation and Hierarchy of Human Needs: : A critical analysis. Retrieved from:http://thoughtleaderpedia.com/MarketingLibrary/AdvertisingDoesn'tWork HierachyOfEffectsModel/8703989Maslows-Hierarchy-of-Needs-A-Critical-Analysis.pdf (Accessed, 15/05/15)

33. Richards, K. 2011. Perceptions about child sex offenders: Trends and issues in crime and criminal justice No.429. Canberra: Australian institute of Criminology.

34. Richter, L, Dawes, A \& Higson-Smith, C. 2004. The many kinds of sexual abuse of young children. Cape Town: HSRC Press.

35. Ruto, SJ. 2009. Sexual abuse of school age children: Evidence from Kenya CICE Hiroshima University.Journal of International Cooperation in education, Vol.12 No 1.

36. Shumba, A. 2001. Sex Education, 'Who guards the guards in schools?'A study of reported abuse by teachers in Zimbabwean secondary schools Vol. 1,(1). University of Botswana: Taylor \& Francis Ltd.

37. Sibanda, N.2009. Quantitative Research. School of Mathematics, Statistics and Operations Research. Victoria University: Wellington.

38. Smith, MJ, 2008. Child sexual abuse: Issues and challenges. Nova Science Publishers, Inc. New

York.

39. Tewksbury, R. 2009. Qualitative versus Quantitative methods: Understanding why qualitative methods are superior for criminology and criminal justice. Journal of Theoretical and Philosophical Criminology, Vol 1(1) University of Louisville.

40. Thompson, S \&Wilkison, 2010. Protecting our children: Understanding and preventing neglect in early childhood. Wadsworth: CengageLearning.

41. Tichapondwa, SM. 2013. Preparing your dissertation at a distance: $A$ research guide. University for small states of the Commonwealth.

a. University press.

42. http://www.netmba.com/mgmt/ob/motivation/maslow (Accessed, 15/05/15). 